\title{
Green tea polyphenol epigallocatechin-3-gallate inhibits thrombin-induced hepatocellular carcinoma cell invasion and $\mathrm{p42} / \mathrm{p} 44-\mathrm{MAPKinase}$ activation
}

\author{
ROLAND KAUFMANN $^{1}$, PETER HENKLEIN ${ }^{2}$, PETRA HENKLEIN ${ }^{2}$ and UTZ SETTMACHER ${ }^{1}$ \\ ${ }^{1}$ Department of General, Visceral and Vascular Surgery, Medical Faculty at the Friedrich Schiller \\ University Jena, Erlanger Allee 101, D-07747 Jena; ${ }^{2}$ Institute of Biochemistry, Charité, \\ Humboldt University of Berlin, Monbijoustr. 2, D-10117 Berlin, Germany
}

Received December 30, 2008; Accepted February 4, 2009

DOI: 10.3892/or_00000349

\begin{abstract}
Thrombin has been recently demonstrated to promote hepatocellular carcinoma (HCC) cell migration by activation of the proteinase-activated receptor (PAR) subtypes $\mathrm{PAR}_{1}$ and $\mathrm{PAR}_{4}$ suggesting a role of these proteinasereceptor systems in HCC progression. In this study, we investigated the effect of (-)-epigallocatechin-3-gallate (EGCG), the major polyphenolic compound of green tea on thrombin-PAR $1 \mathrm{PAR}_{4}$-mediated hepatocellular carcinoma cell invasion and p42/p44 MAPKinase activation. In this study we used the permanent liver carcinoma cell line HEP$3 \mathrm{~B}$ and two primary cultures established from surgically resected HCCs. We found that stimulation of HCC cells with thrombin, the $\mathrm{PAR}_{1}$-selective activating peptide, TFLLRN$\mathrm{NH}_{2}$, and the $\mathrm{PAR}_{4}$-selective activating peptide, AYPGKF$\mathrm{NH}_{2}$, increased cell invasion across a Matrigel-coated membrane barrier and stimulated activation of p42/p44 MAPKinase phosphorylation. Both the effects on p42/p44 MAPKinases, and on cell invasiveness induced by thrombin and the $\mathrm{PAR}_{1 / 4}$ subtype-selective agonist peptides were effectively blocked by EGCG. The results clearly identify EGCG as a potent inhibitor of the thrombin-PAR $1 / \mathrm{PAR}_{4}$-p42/p44 MAPKinase invasive signaling axis in hepatocellular carcinoma cells as a previously unrecognized mode of action for EGCG in cancer cells. Moreover, the results suggest that (-)-epigal-locatechin3-gallate might have therapeutic potential for hepatocellular carcinoma.
\end{abstract}

Correspondence to: Dr Roland Kaufmann, Research Lab., Department of General, Visceral and Vascular Surgery, Research Center Lobeda, Medical Faculty at the Friedrich Schiller University Jena, Erlanger Allee 101, D-07747 Jena, Germany

E-mail: roland.kaufmann@med.uni-jena.de

Key words: thrombin, proteinase-activated receptors, PARs, thrombin receptor, epigallocatechin-3-gallate, hepatocellular carcinoma

\section{Introduction}

Several individual constituents of thrombin-generating pathways have been implicated in neoplasia including coagulation factors VIIa, IXa, Xa and thrombin (IIa) (1-5). Thrombin in particular has multiple cellular effects including induction of cell proliferation and motility, enhancement of vascular permeability, deposition of matrix fibrin, promotion of tumor cell seeding, adhesion to endothelium and extracellular matrix and enhancement of the metastatic capacity of tumors $(6,7)$. These cellular effects of thrombin are mediated at least in part by proteinase-activated receptors (PARs), a subfamily of $\mathrm{G}$ protein-coupled receptors (reviewed in refs. 8-10). Among the PAR family members, $\mathrm{PAR}_{1}(11,12), \mathrm{PAR}_{3}(13)$ and $\mathrm{PAR}_{4}$ (14) are targeted mainly by thrombin. $\mathrm{PAR}_{2}(15)$ can be activated by trypsin, mast cell tryptase, neutrophil proteinase 3, tissue factor/factor VIIa/factor Xa, human kallikrein-related peptidases and membrane-tethered serine proteinase-1/matriptase 1 , but not by thrombin $(9,10)$. In the setting of cancer, the ability of thrombin to act via PARs was highlighted by the demonstration of $\mathrm{PAR}_{1}$ expression in carcinosarcoma and melanoma cells (16), and during the last few years, growing evidence for a function of the PAR family in neoplasia has been obtained (17). Especially for $\mathrm{PAR}_{1}$, a role in the progression of epithelial tumors including breast (18-20), colon (21) and kidney (22) has been shown.

Hepatocellular carcinoma (HCC) is a frequent malignancy worldwide (23) with an extremely poor prognosis, mainly because of HCC recurrence and metastases (24-26). Development and spreading of this tumor entity that are known to be accompanied with complex variations on molecular and cellular level have been studied extensively (reviewed in ref. 27). The understanding of the pathogenesis of HCC is still incomplete, and further studies in this field are warranted to find novel $\mathrm{HCC}$ treatment principles.

We have recently found that $\mathrm{PAR}_{1}$ and $\mathrm{PAR}_{4}$ coordinately regulate thrombin-induced hepatocellular carcinoma cell migration with the involvement of different intracellular effector systems including p42/p44 MAPkinases. Therefore, a role for the thrombin-PAR $1 / 4$-triggered signaling in HCC progression has been suggested (28). In this context, it is 
important to note that hepatocellular carcinoma (HCC) belongs to the 'coagulation type' tumors, in which there is an important role for thrombin formation within the tumor microenvironment $(29,30)$. Therefore, a role of thrombin and its proteolytically activated receptors in HCC under in vivo conditions is very likely.

In the current study we assessed the role of (-)-epigallocatechin-3-gallate (EGCG), an active and major constituent of green tea. This compound has been shown earlier to possess anti-carcinogenic properties in various tumor entities including HCC (31-33). To assess the effect of EGCG on thrombin-induced invasive signaling in hepatocellular carcinoma cells, we used the human permanent HCC cell line HEP-3B, and primary cultures established from surgically resected specimen of primary $\mathrm{HCCs}$. We performed experiments on cell invasion across a Matrigel transmembrane barrier and on activation of p42/p44 MAPKinase phosphorylation. To estimate the involvement of the proteinase-activated receptors $\mathrm{PAR}_{1}$ and $\mathrm{PAR}_{4}$, we elucidated whether EGCG was able to inhibit the invasive effect of PAR subtype-selective peptide agonists (PAR-APs). The results revealed EGCG as a novel antagonist of PAR signaling.

\section{Materials and methods}

Reagents. Human $\alpha$-thrombin (3085 NIH-U/mg protein) was purchased from Haemochrom Diagnostica Supplies (Essen, Germany), epigallocatechin-3-gallate [(-)-cis-2-(3,4,5Trihydroxyphenyl)-3,4-dihydro-1(2H)-benzopyran-3,5,7-triol 3-gallate] was from Sigma-Aldrich Chemie $\mathrm{GmbH}$ (Munich, Germany). The $\mathrm{PAR}_{1}$-selective antagonist SCH 79797 [(N-3cyclopropyl-7-\{[4-(1-methylethyl)phenyl]methyl $\}-7 \mathrm{H}-$ pyrrolo[3,2-f]quinazoline-1,3-diamine)] was purchased from Tocris Bioscience (Ellisville, MO, USA), the $\mathrm{PAR}_{4}$-selective antagonist trans-cinnamoyl-YPGKF-amide from Peptides International (Lousville, KY, USA). Mouse monoclonal phosphospecific antibody to p42/p44 MAPKinase and polyclonal anti-p42/p44 MAPKinase antibody were from Santa Cruz Biotechnology (Santa Cruz, CA, USA).

\section{Cell culture}

Permanent liver carcinoma cell line HEP-3B. Human HEP3B liver carcinoma cells (German Collection of Microorganisms and Cell Cultures, Braunschweig, Germany, ACC 325 and ACC 141) were routinely cultured in RPMI1640 supplemented with $10 \%$ fetal calf serum at $37^{\circ} \mathrm{C}$ in a humidified atmosphere of $5 \% \mathrm{CO}_{2}$. The medium was changed every 2-3 days. For subculturing, treatment with trypsin/ EDTA was used. Since trypsin itself activates PAR-type receptors the subcultured cells were re-fed sufficiently to remove all traces of trypsin.

Primary hepatocellular carcinoma (HCC) cultures. Primary cultures, PHC1 and PHC2, were established from surgically resected specimens of primary hepatocellular carcinomas from patients who underwent surgery in the Department of General, Visceral and Vascular Surgery as described (34). To confirm their epithelial nature and to exclude myofibroblast contam-ination, cell cultures were analyzed by a standard immunochemistry approach, using a monoclonal anti- cytokeratin antibody (DacoCytomation GmbH, Germany, clone MNF116) and an anti-smooth muscle actin antibody (DacoCytomation $\mathrm{GmbH}$, clone 1A4). Cells were cultured in Amniomax-100 (Invitrogen Corporation) at $37^{\circ} \mathrm{C}$ and $5 \% \mathrm{CO}_{2}$ in a humidified incubator.

Peptide synthesis. The peptides TFLLRN-NH 2 and AYPGKF$\mathrm{NH}_{2}$ were synthesized by Fmoc strategy on an ABI-PeptideSynthesizer 433A using TentaGel S RAM resin (capacity $0.24 \mathrm{mmol} / \mathrm{g}$ Rapp Polymere, Tübingen). The cleavage of the peptides from resin was performed with trifluoro acetic acid, $5 \% \mathrm{H}_{2} \mathrm{O}$ und $3 \%$ triisopropylsilane. The peptides were precipitated by ether and lyophilized. Purification of the crude peptide was carried out by using preparative HPLC on a 50x250 mm Kromasil C18-column with a flow rate of $100 \mathrm{ml}$ per minute under standard conditions. The correct mass was determined by MALDI mass spectrometry on a VoyagerDEPRO workstation.

Preparation of cell lysates. The cells were collected by centrifugation at $1,000 \mathrm{x}$ g for $5 \mathrm{~min}\left(4^{\circ} \mathrm{C}\right)$, washed with PBS containing bacitracin $(100 \mu \mathrm{g} / \mathrm{ml})$, PMSF $(0.1 \mathrm{mM})$, pepstatin $\mathrm{A}(1.0 \mu \mathrm{g} / \mathrm{ml})$ and leupeptin $(2.0 \mu \mathrm{g} / \mathrm{ml}), \mathrm{pH} 7.4$, and centrifuged again. The pellet was treated with lysis buffer (PBS, containing 1\% (v/v) Triton X-100, 0.5\% (w/v) deoxycholate and $0.1 \%(\mathrm{w} / \mathrm{v}) \mathrm{SDS}$ for $30 \mathrm{~min}$ at $4^{\circ} \mathrm{C}$, resuspended and centrifuged at $30,000 \mathrm{xg}$ for $15 \mathrm{~min}\left(4^{\circ} \mathrm{C}\right)$.

Western blotting. Proteins of cell lysates were separated on a $12 \%$ SDS/PAGE and transferred to nitrocellulose membranes (BioRad). After blocking in 1\% BSA/1\% skimmed milk for $1 \mathrm{~h}$, the nitrocellulose strips were incubated overnight with the first antibody. Strips were washed 2 times with $0.05 \%$ (v/v) Tween-20 washing buffer, incubated for 45 min with the secondary antibody conjugated to horseradish peroxidase (Santa Cruz Biotechnology) and washed again 2 times as described above. In all of the experiments, the immunoblots were stripped and reprobed with antibodies to total protein to confirm equal protein loading. Secondary antibodies were detected by using chemiluminescence (ECL) Western blotting detection system (Amersham) by exposure to Kodak X-Omat film.

Protein assay. Protein was determined using the DC protein assay system from BioRad Laboratories according to the manufacturer's instructions.

Invasion assay. Tumor cell invasion was measured using a 48-well boyden chamber (NeuroProbe, Inc., Gaithersburg MD, USA). This assay was employed since it has been demonstrated that invasiveness in the assay correlates with the metastatic potential of a given cell line in vivo (36). HCC cell suspension $(51 \mu \mathrm{l})\left(4 \times 10^{5}\right.$ cells in the respective serumfree medium) with or without EGCG were placed in each upper chamber well and $27 \mu 1$ of cell culture medium containing thrombin, the respective peptide agonist or vehicle in each lower well. Then, incubation for $48 \mathrm{~h}$ at $37^{\circ} \mathrm{C}$ in a humidified incubator with $5 \% \mathrm{CO}_{2}$ was performed to allow cell invasion through a polycarbonate filter $(6.5 \mathrm{~mm}$ in diameter, $8-\mu \mathrm{m}$ pore size) precoated with solubilized tissue 

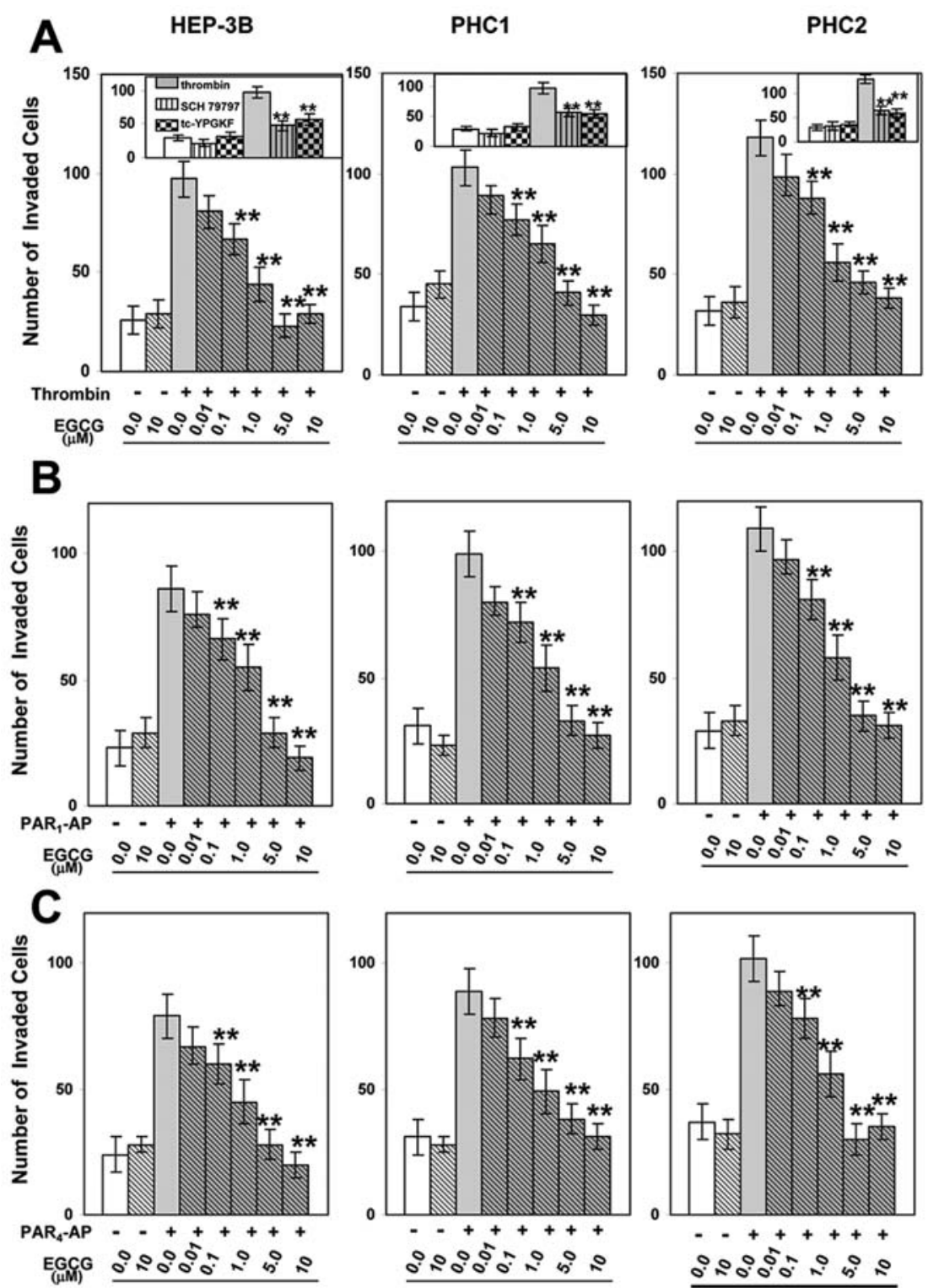

Figure 1. EGCG inhibits the effect of thrombin, the $\mathrm{PAR}_{1}$-selective agonist peptide, TFLLRN-NH${ }_{2}$, and the $\mathrm{PAR}_{4}$-selective agonist, AYPGKF-NH ${ }_{2}$, on invasion of human hepatocellular carcinoma cells. HCC cell invasion was evaluated in a modified Boyden-Chamber assay. Cells (without serum and supplement, respectively) were permitted to invade through a Matrigel-coated polycarbonate membrane in response to (A) thrombin (1.0 NHI-U/ml), (B) TFLLRN-NH $\mathrm{N}_{2}(100 \mu \mathrm{M})$ or (C) AYPGKF-NH $\mathrm{N}_{2}(400 \mu \mathrm{M})$, added to the lower compartment of the chamber. Before stimulation cells were preincubated for $30 \mathrm{~min}$ with vehicle and EGCG, respectively. After $48 \mathrm{~h}$, cells that invaded across the Matrigel were fixed, stained and quantified by microscopic counting. Bars represent the mean values $+\mathrm{SD}$ of octuplicates obtained in one experiment, which is representative for three independent assays. ${ }^{* *} \mathrm{P}<0.05$ vs. agonist stimulated. Inset (1A-C) the $\mathrm{PAR}_{1}$-selective antagonist $\mathrm{SCH} 79797$ and the $\mathrm{PAR}_{4}$-selective antagonist trans-cinnamoyl-YPGKF-NH ${ }_{2}$ inhibit the effect of thrombin on cell invasion. The cells serum-starved for $17 \mathrm{~h}$ were preincubated for $10 \mathrm{~min}$ with vehicle, SCH 79797 (10 $\mu \mathrm{M})$ and trans-cinnamoyl-YPGKF$\mathrm{NH}_{2}(400 \mu \mathrm{M})$, respectively, and then the invasion assay was performed as described. ( $\mathrm{SCH} 79797=\mathrm{PAR}_{1}$-selective antagonist $\mathrm{SCH} 79797$; tcYPGKF=PAR ${ }_{4}$-selective antagonist, trans-cinnamoyl-YPGKF- $\mathrm{NH}_{2}$ ). Bars represent the mean values $\pm \mathrm{SD}$ of octuplicates obtained in one experiment, which is representative for three independent assays. ${ }^{* *} \mathrm{P}<0.05$ vs. thrombin-stimulated.

basement membrane (Matrigel; BD Biosciences Discovery Labware, Bedford, MA, USA). After the incubation period, the filter was removed, and its upper side was wiped gently with a cotton tip swab to remove non-migrated cells. The migrated cells on the lower surface of the membrane were fixed with 96\% ethanol, stained with Giemsa solution, and counted under a Zeiss Axiolab microscope. Data were acquired from three independent experiments, involving octuplicate measurements for each condition. To exclude effects by cell proliferation control experiments with the proliferation inhibitor, mitomycin $(10 \mu \mathrm{g} / \mathrm{ml}, 3 \mathrm{~h}$ preincubation), were performed.

Estimation of cell viability. For testing the effect of EGCG on HCC cell viability cells were seeded into 24-well plates and treated with the respective inhibitor for $48 \mathrm{~h}$. Then the viable cells were counted by trypan blue dye exclusion test.

Statistical analysis. All results from migration experiments are expressed as means \pm SD for one experiment performed 


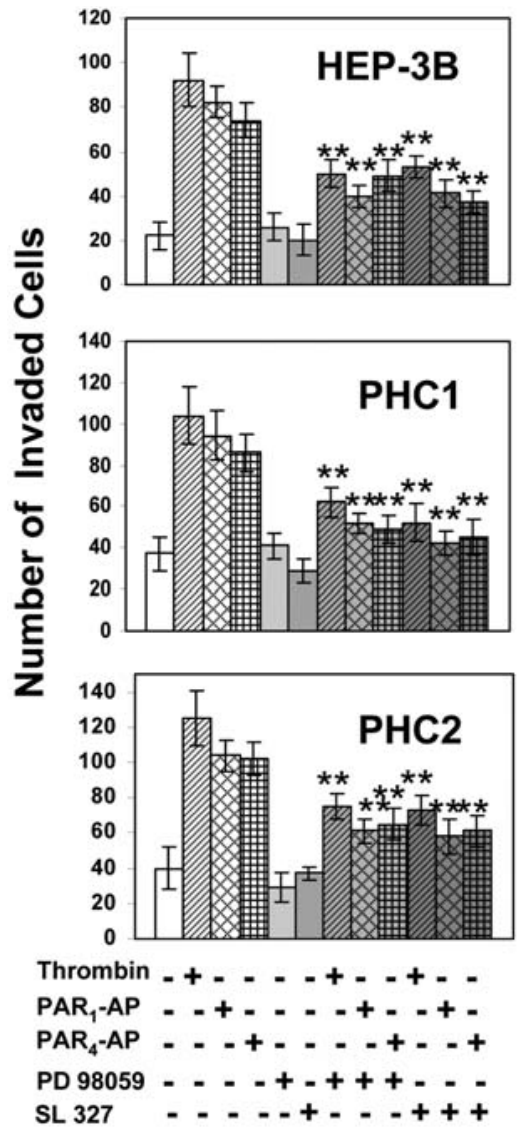

Figure 2. Inhibition of thrombin- $\mathrm{PAR}_{1} / \mathrm{PAR}_{4}$-stimulated invasion of $\mathrm{HCC}$ cells is mediated by p42/p44 MAPKinase activation. Serum-starved HEP3B cells, cells from PHC-1 and PHC-2 cells, respectively, were plated on top of a Matrigel-coated polycarbonate membrane. Cells were preincubated for $30 \mathrm{~min}$ with vehicle, MEK inhibitor, SL $372(5.0 \mu \mathrm{M})$, and MEK inhibitor, PD $98059(10 \mu \mathrm{M})$, respectively. Cell invasion in response to the respective stimulus was analysed after $48 \mathrm{~h}$, as described in the legend for Fig. 1. Representative results from three independent experiments are shown. ${ }^{* *} \mathrm{P}<0.05$ vs. non stimulated control.

in octuplicate. Differences between data were tested by using the SPSS 13 for Windows computer program (SPSS Inc., Chicago, IL, USA). As the data were not normally distributed non-parametric Mann-Whitney U test was used. $\mathrm{P}<0.05$ was considered to be significant.

\section{Results}

EGCG inhibits thrombin-induced increase in HCC cell invasion mediated by $P A R_{1}$ and $P A R_{4}$. A modified Boyden chamber Matrigel invasion assay with cells from the permanent HCC cell line HEP-3B and primary HCC cultures, established from surgically resected hepatocellular carcinomas was performed to determine if EGCG was capable of inhibiting thrombin-PAR-induced invasion. As demonstrated in Fig. 1A, thrombin (1.0 NHI-U/ml) significantly enhanced HCC cell invasion across the Matrigel barrier. To elucidate the PAR-subtype(s) involved in the thrombin-triggered stimulation of HCC cell invasion, we performed experiments with PAR-subtype selective agonists and antagonists (SCH 79797 for $\mathrm{PAR}_{1}$ and trans-cinnamoylYPGKF-NH $\mathrm{N}_{2}$ for $\mathrm{PAR}_{4}$ ). Both the $\mathrm{PAR}_{1}$ selective agonist
Table I. EGCG $(10 \mu \mathrm{M})$ inhibits the effect of thrombin, the $\mathrm{PAR}_{1}$ - selective peptide TFLLRN-NH${ }_{2}$ and the PAR ${ }_{4}^{-}$ selective peptide AYPGKF-NH $\mathrm{N}_{2}$ on $\mathrm{p} 42 / \mathrm{p} 44$ MAPKInase activation in $\mathrm{HCC}$ primary cultures.

\begin{tabular}{lccc}
\hline \multirow{2}{*}{ Cell culture } & \multicolumn{3}{c}{$\mathrm{p} 42 / \mathrm{p} 44$ MAPKinase } \\
\cline { 2 - 4 } & Thro & $\mathrm{PAR}_{1}$ & PAR $_{4}$ \\
PHC1 & $91.6 \pm 8.3$ & $84.3 \pm 12.4$ & $89.0 \pm 7.4$ \\
PHC2 & $88.5 \pm 10.8$ & $85.5 \pm 11.9$ & $93.0 \pm 11.4$ \\
\hline
\end{tabular}

Thro, \% Inhibition \pm SD of the effect of thrombin $(1.0 \mathrm{NHI}-\mathrm{U} / \mathrm{ml})$; $\mathrm{PAR}_{1}, \%$ Inhibition $\pm \mathrm{SD}$ of the effect of TFLLRN-NH $(100 \mu \mathrm{M})$; $\mathrm{PAR}_{4}, \%$ Inhibition $\pm \mathrm{SD}$ of the effect of AYPGKF-NH $\mathrm{N}_{2}(400 \mu \mathrm{M})$; Data are from three independent experiments.

TFLLRN-NH ${ }_{2}\left(100 \mu \mathrm{M}\right.$; Fig. 1B) and the $\mathrm{PAR}_{4}$ selective agonist AYPGKF-NH $\mathrm{N}_{2}(400 \mu \mathrm{M}$; Fig. 1C) significantly enhanced the invasive capacity of cells from the permanent HCC cell line HEP-3B and from primary HCC cultures, PHC1, PHC2, across Matrigel. The receptor-inactive control peptides, NRLLFT- $\mathrm{NH}_{2}$ for $\mathrm{PAR}_{1}$, and YAPGKF-NH $\mathrm{NH}_{2}$ for $\mathrm{PAR}_{4}$, were unable to induce an effect on hepatocellular carcinoma cell invasion (data not shown), thereby unspecific effects of the peptide sequences may be excluded. For subtype selective receptor inhibition, the $\mathrm{PAR}_{1}$-selective antagonist SCH $79797\left[10 \mu \mathrm{M}\right.$; (36)] and the $\mathrm{PAR}_{4}$-selective antagonist, trans-cinnamoyl-YPGKF- $\mathrm{NH}_{2}$ [400 $\mu \mathrm{M}$; tcY$\mathrm{NH}_{2}$; (37)], were used. As demonstrated in the insets of Fig. 1A-C, both SCH 79797 and trans-cinnamoyl-YPGKF-NH reduced thrombin's stimulatory action on the HCC cell invasive capacity.

Pretreatment of the cells for 30 min with EGCG inhibited the effect of thrombin (Fig. 1A) and the PAR-selective agonist peptides (Fig. 1B and C) on HCC cell invasion in a concentration-dependent manner. It is important to note that EGCG concentrations as low as $1.0 \mu \mathrm{M}$, close to physiologically relevant level observed after dietary or supplemental intake (38-40) had significant inhibition capacity. In addition, 0.01-10 $\mu \mathrm{M}$ concentrations of EGCG did not inhibit basal levels of HCC cell invasion compared with untreated control (Fig. 1A-C) and had no significant effect on cell viability as evaluated by trypan blue exclusion test (data not shown).

EGCG inhibits the effect of thrombin, TFLLRN-NH $\mathrm{H}_{2}$ and AYPGKF $-\mathrm{NH}_{2}$ on $\mathrm{p} 42 / p 44$ MAPKinase activation that is involved in thrombin/PAR $1 / 4$-stimulated HCC cell invasion. To explore the effect of EGCG on intracellular signaling level in HCC cells, we focused on p42/p44 MAPKinases that are known to be a critically involved in hepatocarcinogenesis (reviewed in refs. 41 and 42). Using the MEK inhibitors, PD 98059 and SL 327, both inhibited the effect of either, thrombin or the $\mathrm{PAR}_{1}$ selective agonist peptide, TFLLRN$\mathrm{NH}_{2}$, or the $\mathrm{PAR}_{4}$ selective agonist AYPGKF-NH $\mathrm{NH}_{2}$ on HEP-3B cell invasion (Fig. 2) indicating the involvement of p42/p44 


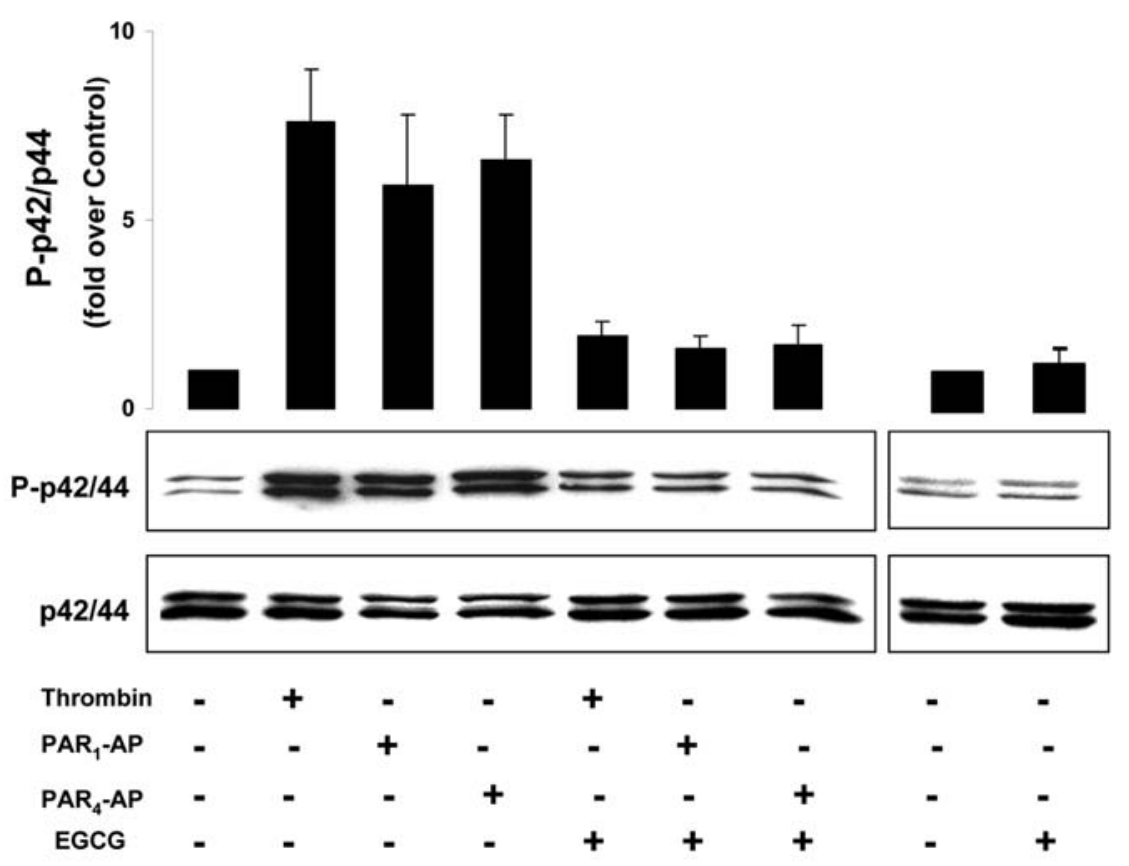

Figure 3. PAR ${ }_{1}$-AP TFLLRN-NH ${ }_{2}$ and PAR $_{4}$-AP AYPGKF-NH $H_{2}$ induce activation of p42/44 MAPKinase in HEP-3B cells. Serum-starved HEP-3B cells were treated with thrombin $(1.0 \mathrm{NIH}-\mathrm{U} / \mathrm{ml}), \mathrm{PAR}_{1}$-AP TFLLRN-NH $(100 \mu \mathrm{M})$ or PAR $\mathrm{P}_{4}$-AP AYPGKF-NH $(400 \mu \mathrm{M})$ for 20 min. The cell lysates were subjected to SDS-PAGE and Western blotting with an anti-phospho-p42/44 MAPKinases antibody. Immunoblot analysis from a representative experiment is shown with total p42/44 MAPKinase as control for constant protein loading in all lanes. The data are expressed as the fold increase over untreated control (mean \pm $\mathrm{SD}$ ) from three independent experiments in the histograms above the blots. P-p42/p44 = phosphorylated p42/p44 MAPKinases.

MAPKinases in thrombin-PAR $1 / \mathrm{PAR}_{4}$ invasive effect. Similar results were observed in cells from the HCC primary cultures, PHC1 and PHC2 (Fig. 2).

Stimulation of HEP-3B cells with the $\mathrm{PAR}_{1}$ selective agonist peptide, TFLLRN-NH , or the $\mathrm{PAR}_{4}$ selective agonist AYPGKF- $\mathrm{NH}_{2}$, for 20 min caused a significant increase in phospho-p42/p44 MAPKinases, consistent with a concurrence of MAPKinase activation (Fig. 3). In keeping with its ability to activate $\mathrm{PAR}_{1}$ and $\mathrm{PAR}_{4}$, thrombin also induced a strong increase in phosphorylation of p42/p44 MAPKinases in HEP-3B cells (Fig. 3). As seen in Fig. 3, EGCG $(10 \mu \mathrm{M})$ potently inhibited the increase in $\mathrm{p} 42 / \mathrm{p} 44$ activation in HEP-3B cells induced by thrombin, the $\mathrm{PAR}_{1}$ activating peptide TFLLRN-NH $\mathrm{N}_{2}$ and the PAR4 activating peptide AYPGKF-NH ${ }_{2}$, respectively. As further demonstrated, EGCG $(10 \mu \mathrm{M})$ by itself had no significant effect on MAPKinase phosphorylation basal level in HEP-3B liver carcinoma cells (Fig. 3). A comparable inhibitory effect of EGCG on p42/p44 activation could be observed in cells from the primary $\mathrm{HCC}$ cultures, PHC1 and PHC2 (Table I).

\section{Discussion}

In this study we found that (-)-epigallocatechin-3-gallate, an active and major constituent of green tea, inhibits the $\mathrm{PAR}_{1} /$ $\mathrm{PAR}_{4}$-mediated effect of the serine proteinase thrombin on HCC cell invasiveness and p42/p44 MAPKinase activation. In cells from the permanent HCC cell line HEP-3B and cells from primary cultures established from surgically resected hepatocellular carcinoma specimens thrombin stimulates cell invasion by interaction with PAR subtypes, $\mathrm{PAR}_{1}$ and $\mathrm{PAR}_{4}$.
Our conclusions are based on the ability of the PAR-targeted agonists for PARs 1 and 4 to mimic the actions of thrombin and the block of thrombin action by the two PAR antagonists, $\mathrm{SCH}_{79797}$ for $\mathrm{PAR}_{1}(36)$, and trans-cinnamoyl-YPGKF-NH for $\mathrm{PAR}_{4}$ (37). The receptor-inactive PAR-AP sequencerelated peptides (NRLLFT-NH $\mathrm{N}_{2}$ for $\mathrm{PAR}_{1}$; YAPGKF-NH $\mathrm{NH}_{2}$ for $\mathrm{PAR}_{4}$ ) did not affect $\mathrm{HCC}$ cell invasion, thereby establishing further the receptor selectivity of the PAR-activating peptides we used to activate PARs 1 and 4.

As the main finding of the study we report that EGCG is an inhibitor of the thrombin-stimulated cell invasion in HCC cells mediated by the proteinase activated receptors, $\mathrm{PAR}_{1}$ and $\mathrm{PAR}_{4}$. This was concluded since EGCG inhibited both the effect of the endogeneous PAR agonist thrombin and selective PAR subtype selective agonists (TFLLRN-amide for $\mathrm{PAR}_{1}$ and $\mathrm{AYPGKF}$-amide for $\mathrm{PAR}_{4}$ ) that mimicked the effect of proteolytic PAR activation by thrombin. Moreover, EGCG inhibited the thrombin- $\mathrm{PAR}_{1} / \mathrm{PAR}_{4}$-induced phosphorylation-activation of p42/p44 MAPKinases, and inhibition of these kinases by pharmacological agents (PD 98059 and SL327) resulted in an inhibition of thrombin- $\mathrm{PAR}_{1} / \mathrm{PAR}_{4}$ stimulated invasive capacity of HCC cells. Therefore, it may be concluded that EGCG inhibits $\mathrm{PAR}_{1} / \mathrm{PAR}_{4}$-triggered invasion via inhibition of p42/p44 MAPKinases. Our conclusion is based on the experiments demonstrating that thrombin, the $\mathrm{PAR}_{1}-\mathrm{AP}$ and the $\mathrm{PAR}_{4}$-AP strongly increased the phosphorylation of p42/p44 MAPKinases and EGCG inhibited thrombin-PAR $1 / \mathrm{PAR}_{4}$-stimulated $\mathrm{p} 42 / \mathrm{p} 44$ MAPKinase phosphorylation in HCC cells. Therefore, it seems that $\mathrm{p} 42 / \mathrm{p} 44$ MAPKinases activation may be required for the thrombin- $\mathrm{PAR}_{1} / \mathrm{PAR}_{4}$-stimulated $\mathrm{HCC}$ cell invasion. 
This hypothesis may be further strengthened by the observation that PD98059 and SL327, selective inhibitors of p42/p44 MAPKinases, decreased the invasive effect of thrombin and the PAR agonist peptides.

(-)-Epigallocatechin-3-gallate is known to possess antioxidant (43), anti-proteolytic $(44,45)$, and anti-proliferative activity (46). More detailed, in vivo mouse studies have established that EGCG can function as a strong chemopreventative agent against cancer development and progression $(47,48)$, and epidemiological and preclinical studies have demonstrated that catechins derived from green tea have profound chemopreventative and antitumor effects $(38,48,49)$. The mechanisms by which EGCG is able to produce these effects is wide-ranging and includes e.g. inhibition of growth factor signaling pathways and numerous kinases JNK, AP-1, p44/p42 MAPK (for reviews see e.g. 38,50).

With our study on hepatocellular carcinoma cells we have identified a novel mechanism for the anti-carcinogenic effects of EGCG, the inhibition of thrombin induced cancer cell invasion. Since the ability of cancer cells to invade is one of the hallmarks of the metastatic phenotype and more specifically, post-extravasation cell migration and invasion is known to be critical for the metastatic process in hepatocellular carcinoma (51), EGCG may have therapeutic potential for hepatocellular carcinoma.

\section{Acknowledgements}

We would like to thank Beate Schulze, Elke Oswald and Gabriele Weigand, Research Lab., Department of General, Visceral and Vascular Surgery, for the excellent technical assistance.

\section{References}

1. Zacharski LR, Wojtukiewicz MZ, Costantini V, Ornstein DL and Memoli VA: Pathways of coagulation/ fibrinolysis activation in malignancy. Semin Thromb Hemost 18: 104-116, 1992.

2. Zacharski LR: Anticoagulants in cancer treatment: malignancy as a solid-phase coagulopathy. Cancer Lett 186: 1-9, 2002.

3. Vlodavsky I, Ilan N, Nadir Y, et al: Heparanase, heparin and the coagulation system in cancer progression. Thromb Res 120 (Suppl 2): S112-S120, 2007.

4. Borensztajn K, Peppelenbosch MP and Spek CA: Factor Xa: at the crossroads between coagulation and signaling in physiology and disease. Trends Mol Med (In press).

5. Palumbo JS: Mechanisms linking tumor cell-associated procoagulant function to tumor dissemination. Semin Thromb Hemost 34: 154-160, 2008.

6. Lynn M, Nierodzik ML, Kajumo LR and Karpatkin S: Effect of thrombin treatment of tumor cells on adhesion of tumor cells to platelets in vitro and tumor metastasis in vivo. Cancer Res 52: 3267-3272, 1992.

7. Hu L, Lee M, Campbell W, Perez-Soler R and Karpatkin S: Role of endogenous thrombin in tumor implantation, seeding, and spontaneous metastasis. Blood 104: 2746-2751, 2002.

8. Ossovskaya VS and Bunnett NW: Protease-activated receptors: contribution to physiology and disease. Physiol Rev 84: 579$621,2004$.

9. Steinhoff M, Buddenkotte J, Shpacovitch V, et al: Proteinaseactivated receptors: transducers of proteinase-mediated signaling in inflammation and immune response. Endocr Rev: 26: $1-43,2005$.

10. Ramachandran R and Hollenberg MD: Proteinases and signaling: pathophysiological and therapeutic implications via PARs and more. Br J Pharmacol 153: S263-S282, 2007.

11. Vu TK, Hung DT, Wheaton VI and Coughlin SR: Molecular cloning of a functional thrombin receptor reveals a novel proteolytic mechanism of receptor activation. Cell 64: 1057-1068, 1991.
12. Rasmussen UB, Vouret-Craviari V, Jallat S, et al: cDNA cloning and expression of a hamster alpha-thrombin receptor coupled to $\mathrm{Ca}^{2+}$ mobilization. FEBS Lett 288: 123-128, 1991.

13. Ishihara H, Connolly AJ, Zeng D, et al: Protease-activated receptor 3 is a second thrombin receptor in humans. Nature 386: 502-506, 1997.

14. Xu WF, Andersen H, Whitmore TE, et al: Cloning and characterization of human protease-activated receptor 4 . Proc Natl Acad Sci USA 95: 6642-6646, 1998.

15. Nystedt S, Emilsson K, Wahlestedt C and Sundelin J: Molecular cloning of a potential proteinase activated receptor. Proc Natl Acad Sci USA 91: 9208-9212, 1994.

16. Wojtukiewicz MZ, Tang DG, Ben-Josef E, Renaud C, Walz DA and Honn KV: Solid tumor cells express functional 'tethered ligand' thrombin receptor. Cancer Res 55: 698-704, 1995.

17. Camerer E: Protease signaling in tumour progression. Thromb Res 120 (Suppl 2): S575-S581, 2007.

18. Even-Ram SC, Maoz M, Pokroy E, et al: Thrombin receptor overexpression in malignant and physiological invasion processes. Nat Med 4: 909-914, 1998.

19. Even-Ram SC, Maoz M, Pokroy E, et al: Tumor cell invasion is promoted by activation of protease activated receptor- 1 in cooperation with the alpha v beta 5 integrin. J Biol Chem 276: 10952-10962, 2001.

20. Henrikson KP, Salazar SL, Fenton JW and Pentecost BT: Role of thrombin receptor in breast cancer invasiveness. Br J Cancer 179: 401-406, 1999.

21. Darmoul D, Gratio V, Devaud H, Lehy T and Laburthe M: Aberrant expression and activation of the thrombin receptor protease-activated receptor- 1 induces cell proliferation and motility in human colon cancer cells. Am J Pathol 162: $1503-1513,2003$

22. Bergmann S, Junker K, Henklein P, Hollenberg MD, Settmacher U and Kaufmann R: PAR-type thrombin receptors in renal carcinoma cells: PAR1-mediated EGFR activation promotes cell migration. Oncol Rep 15: 889-893, 2006.

23. Bosch FX, Ribes J, Cleries R and Diaz M: Epidemiology of hepatocellular carcinoma. Clin Liver Dis 9: 191-211, 2005.

24. Okuda K: Hepatocellular carcinoma. J Hepatol 32: 225-237, 2000.

25. Poon RT, Fan ST, Lo CM, Liu CL and Wong J: Long-term survival and pattern of recurrence after resection of small hepatocellular carcinoma in patients with preserved liver function: implications for a strategy of salvage transplantation. Ann Surg 235: 373-382, 2002.

26. Wands JR: Prevention of hepatocellular carcinoma. N Engl J Med 351: 1567-1570, 2004.

27. Avila MA, Berasain C, Sangro B and Prieto J: New therapies for hepatocellular carcinoma. Oncogene 25: 3866-3884, 2006.

28. Kaufmann R, Rahn S, Pollrich K, et al: Thrombin-mediated hepatocellular arcinoma cell migration: cooperative action via proteinase-activated receptors 1 and 4 . J Cell Physiol 211: 699-707, 2007.

29. Zacharski LR, Memoli VA, Costantini V, Wojtukiewicz MZ and Ornstein DL: Clotting factors in tumour tissue: implications for cancer therapy. Blood Coagul Fibrinolysis 1: 71-78, 1990.

30. Zacharski LR, Hommann M and Kaufmann R: Rationale for clinical trials of coagulation: reactive drugs in hepatocellular carcinoma. Expert Rev Cardiovasc Ther 2: 777-784, 2004.

31. Katiyar SK and Mukhtar H: Tea consumption and cancer. In: World Review Nutrition and Dietetic, Simopoulos AP (ed.). Vol. 19, Karger, Basel, pp154-184, 1996.

32. Nakajima T, Moriguchi M, Jo M, et al: A green tea polyphenol, epigalocatechin-3-gallate, induces apoptosis of human hepatocellular carcinoma, possibly through inhibition of Bcl-2 family proteins. J Hepatol 44: 1074-1082, 2006.

33. Song HU and Hwang SG: Prevention of hepatocellular carcinoma. Korean J Gastroenterol 49: 201-208, 2007.

34. Kaufmann R, Junker U, Nuske K, et al: PAR-1- and PAR-3type thrombin receptor expression in primary cultures of human renal cell carcinoma cells. Int J Oncol 20: 177-180, 2002.

35. Albini A, Iwamoto Y, Kleinman HK, et al: A rapid in vitro assay for quantitating the invasive potential of tumour cells. Cancer Res 47: 3239-3245, 1987.

36. Ahn HS, Foster C, Boykow G, Stamford A, Manna M and Graziano M: Inhibition of cellular action of thrombin by N3cyclopropyl-7-[[4-(1-methylethyl)phenyl]methyl]-7Hpyrrolo[3,2-f]quinazoline-1,3-diamine ihydrochloride $(\mathrm{SCH}$ 79797), a nonpeptide thrombin receptor antagonist. Biochem Pharmacol 60: 1425-1434, 2000. 
37. Hollenberg MD and Saifeddine M: Proteinase-activated receptor 4 (PAR4): activation and inhibition of rat platelet aggregation by PAR4-derived peptides. Can J Physiol Pharmacol 79: 439-442, 2001

38. Lambert JD and Yang CS: Mechanisms of cancer prevention by tea constituents. J Nutr 133: S3262-S3267, 2003.

39. Elbling L, Weiss RM, Teufelhofer O, et al: Green tea extract and (-)-epigallocatechin-3-gallate, the major tea catechin, exert oxidant but lack antioxidant activities. FASEB J 19: 807-809, 2005.

40. Chu KO, Wang CC, Chu CY, et al: Pharmacokinetic studies of green tea catechins in maternal plasma and fetuses in rats. J Pharm Sci 95: 1372-1378, 2008.

41. Gollob JA, Wilhelm S, Carter C and Kelley SL: Role of Raf kinase in cancer: therapeutic potential of targeting the Raf/MEK/ERK signal transduction pathway. Semin Oncol 33: 392-406, 2006

42. Pang RW and Poon RT: From molecular biology to targeted therapies for hepatocellular carcinoma: the future is now. Oncology 72 (Suppl 1): 30-44, 2007.

43. Katiyar SK and Elmets CA: Green tea polyphenolic antioxidants and skin photoprotection. Int J Oncol 18: 1307-1313, 2001.

44. Nam S, Smith DM and Dou QP: Ester bond-containing tea polyphenols potently inhibit proteasome activity in vitro and in vivo. J Biol Chem 276: 13322-13330, 2001.
45. Annabi B, Lachambre MP, Bousquet-Gagnon N, Page M, Gingras D and Beliveau R: Green tea polyphenol (-)-epigallocatechin 3-gallate inhibits MMP-2 secretion and MT1-MMPdriven migration in glioblastoma cells. Biochim Biophys Acta 1542: 209-220, 2002.

46. Otsuka T, Ogo T, Eto T, Asano Y, Suganuma M and Niho Y: Growth inhibition of leukemic cells by (-)-epigallocatechin gallate, the main constituent of green tea. Life Sci 63: 1397-1403, 1998.

47. Fujiki H, Suganuma M, Imai K and Nakachi K: Green tea: cancer preventive beverage and/or drug. Cancer Lett 188: 9-13, 2002.

48. Crespy V and Williamson G: A review of the health effects of green tea catechins in in vivo animal models. J Nutr 134 (Suppl 12): S3431-S3440, 2004.

49. Yang CS, Lambert JD, Ju J, Lu G and Sang S: Tea and cancer prevention: molecular mechanisms and human relevance. Toxicol Appl Pharmacol 224: 265-273, 2007.

50. Shankar S, Ganapathy S and Srivastava RK: Green tea polyphenols: biology and therapeutic implications in cancer. Front Biosci 12: 4881-4899, 2007.

51. Hangan D, Uniyal S, Morris VL, von Ballestrem C, Uniyal S and Chan BM: Integrin VLA-2 $\left(\alpha_{2} \beta_{1}\right)$ function in postextravasation movement of human rhabdomyosarcoma RD cells in the liver. Cancer Res 56: 3142-3147, 1996. 